\title{
Rancang Bangun Sistem Peminjaman Laptop dengan Metode Extreme Programming Menggunakan Framework Bootstrap
}

\author{
(Studi Kasus PT Gramedia)
}

\author{
Goldie Gunadi \\ Teknik Informatika, STMIK Widuri Jakarta, Jakarta Selatan, Indonesia \\ send2goldie@gmail.com
}

Diterima 31 Mei 2021

Disetujui 24 Juni 2021

\begin{abstract}
PT Gramedia is a company engaged in the printing industry. Currently, PT Gramedia provides facilities for a number of laptops that can be lent to employees to support their work needs. During the current COVID-19 pandemic, PT Gramedia requires some of its employees to work from home. This results in the increasing need for employees to work devices in the form of laptops. The research conducted aims to design and build a web-based laptop lending information system using the Bootstrap 4 framework, which is intended to help make the data collection and administration process faster, easier and more efficient in terms of time, cost, place and energy. From the results of the research, a system was built according to user needs and was able to solve existing problems. In addition, the resulting system is also more flexible and dynamic and can be accessed from a variety of different types of devices.
\end{abstract}

Index Terms-Bootstrap; extreme programming; information system; laptop rental

\section{PENDAHULUAN}

Didirikan pada tahun 1972 sebagai salah satu unit bisnis Kompas Gramedia, PT. Gramedia telah membuktikan dirinya sebagai salah satu perusahaan penyedia jasa cetak terkemuka di Indonesia. PT. Gramedia yang kini lebih dikenal dengan nama Gramedia Printing terus mengembangkan bisnisnya, baik di Indonesia maupun di pasar Internasional. Berbagai jenis produk yang dihasilkan sebagian besar berupa: koran, tabloid, majalah, buku dan produk kemasan. Hingga saat ini PT. Gramedia telah memiliki sejumlah kantor cabang dan pabrik yang tersebar di wilayah Indonesia, yakni: Jakarta, Cikarang, Bandung, Semarang, Surabaya, Medan, dan Bali[1]

Untuk mendukung aktivitas karyawan agar dapat bekerja secara optimal, PT. Gramedia menyediakan fasilitas atau alat kerja yang dibutuhkan termasuk juga perangkat laptop sesuai dengan kebutuhan fungsi dan deskripsi pekerjaan karyawan. PT Gramedia melalui Departemen Information Technology Operation (ITO) juga menyediakan sejumlah laptop yang dapat dipinjam oleh karyawan bilamana diperlukan dalam pekerjaanya atau sebagai perangkat cadangan (backup) apabila laptop yang digunakannya saat ini mengalami gangguan atau kerusakan dan perlu diperbaiki untuk sementara waktu.

Kebijakan pemerintah yang mewajibkan setiap perusahaan agar membatasi jumlah karyawan yang bekerja di kantor sebagai dampak dari adanya pandemic virus COVID-19 mengakibatkan sejumlah karyawan terpaksa harus bekerja dari rumah atau yang dikenal dengan istilah Work From Home (WFH)[2]. Kondisi ini tentu saja berdampak kepada meningkatnya transaksi peminjaman laptop yang dilakukan oleh karyawan sehingga proses administrasinya pun perlu dikelola dengan baik.

Saat ini semua transaksi peminjaman laptop hanya dicatat secara manual dalam sebuah buku. Hal ini tentu saja mengakibatkan kesulitan dalam kegiatan administrasi dan pembuatan laporan yang diperlukan. Untuk mengatasi permasalahan tersebut diperlukan sebuah sistem informasi agar proses pengolahan data minjaman laptop dapat dilakukan secara terkomputerisasi.

Tujuan dari penelitian ini adalah merancang dan membangun sebuah sistem informasi peminjaman laptop berbasis web dengan menggunakan metode XP (Extreme Programming) dan framework Bootstrap 4. Penggunaan metode XP diharapkan dapat menghasilkan sebuah perangkat lunak yang lebih adaptif dan fleksibel terhadap kebutuhan perusahan. Framework Bootstrap digunakan untuk mempermudah dan mempersingkat proses perancangan dan pengkodean yang dilakukan sehubungan dengan tahapan metode XP.

Penelitian dari Yusnia Budiarti dan Risyanto dengan judul: Implementasi Metode Extreme Programming Untuk Merancang Sistem Informasi Pendaftaran Siswa Baru Berbasis Web Pada SMK Multimedia Mandiri Jakarta[3], menunjukkan bahwa sistem yang dibangun telah sesuai dengan kebutuhan 
pengguna. Pada penelitian ini proses perancangan dilakukan menggunakan UML dan proses pengkodean dilakukan dengan menggunakan bahasa pemrograman HTML, CSS, JavaScript dan PHP. Sedangkan untuk implementasi basis datanya menggunakan MySQL.

Hasil dari penelitian ini diharapkan dapat membantu PT. Gramedia dalam meningkatkan kinerja karyawan dan mendukung proses bisnis yang dilakukan agar dapat terus produktif khusunya di masa pandemi COVID-19 yang sedang berlangsung hingga saat ini.

\section{LANDASAN TEORI}

\section{A. Extreme Programming $(X P)$}

XP merupakan salah satu metodologi yang digunakan dalam rekayasa perangkat lunak dan banyak digunakan oleh para pengembang aplikasi ataupun sistem informasi[4]. Menurut Dwiky Andika[5], XP merupakan pendekatan atau model pengembangan perangkat lunak yang mencoba menyederhanakan berbagai tahapan dalam proses pengembangan sehingga metode ini menjadi lebih adaptif dan fleksibel. XP bukan hanya berfokus pada pengkodean namun juga meliputi seluruh area pengembangan perangkat lunak. XP mengambil pendekatan 'ekstrim' dalam iterative development atau teknik pengembangan melalui siklus yang berulang.

Gambar 1 menunjukkan tahapan pengembangan dengan metode XP yang meliputi: perencanaan (planning), perancangan (design), pembuatan kode program (coding) dan pengujian (testing)[6].

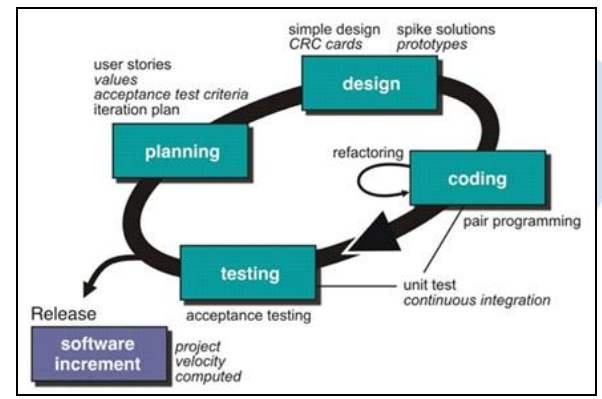

Gambar 1. Tahapan extreme programming[6]

\section{B. Framework Bootstrap}

Bootstrap[7] merupakan front-end framework yang intuitif dan powerful untuk pengembangan aplikasi web yang lebih cepat dan mudah. Bootstrap menggunakan HTML, CSS dan JavaScript.

Bootstrap menyediakan sejumlah fitur untuk mendukung pengembang perangkat lunak menghasilkan aplikasi yang kompatibel dengan berbagai perangkat bergerak. Berikut ini adalah fiturfitur dari framework Bootstrap[8]:

- Komponen siap pakai
- Kompatibilitas web browser

- Mendukung Responsive Web Design

- CSS yang fleksibel

- JavaScript siap pakai

Untuk mempermudah pembuatan antarmuka pengguna, Bootstrap 4 menyediakan sejumlah komponen yang dapat digunakan[9]. Berikut adalah komponen-komponen yang digunakan dalam pembuatan sistem peminjaman laptop ini:

1) Buttons; digunakan untuk membuat tombol.

2) Forms; digunakan untuk membuat formulir yang berisi sejumlah elemen sebagai sarana untuk menerima masukan (input) dari pengguna.

3) Modal; digunakan untuk menambahkan kotak dialog ke sebuah halaman website.

4) Navs; digunakan untuk membuat menu navigasi halaman website.

\section{Metode Penelitian}

\section{A. Metode Pengumpulan Data}

Pengumpulan data-data yang diperlukan dalam penelititan diperoleh melalui beberapa cara:

1) Observasi, dengan melakukan pengamatan langsung di lapangan terhadap metode atau prosedur peminjaman laptop yang berjalan di PT. Gramedia saat ini.

2) Wawancara, dilakukan terhadap petugas administrasi peminjaman di Departemen ITO dan pimpinan terkait serta sejumlah karyawan yang melakukan peminjaman laptop.

3) Studi pustaka, melalui berbagai sumber referensi, seperti: artikel di internet, buku referensi maupun juga jurnal-jurnal penelitian ilmiah yang berhubungan.

\section{B. Metode Pengembangan Extreme Programming}

Berdasarkan pada tahapan-tahapan tessebut, kegiatan yang dilakukan dalam rancang bangun Sistem Peminjaman Laptop dengan metode XP meliputi:

1) Perencanaan

Proses perencanaan dimulai dari mengidentifikasi permasalahan yang timbul pada sistem berjalan, kemudian dilakukan analisa kebutuhan terhadap sistem yang akan dibangun. Analisa kebutuhan yang dilakukan meliputi kebutuhan pengguna dan kebutuhan bisnis. Kebutuhan pengguna terdiri dari kebutuhan fungsional dan non fungsional, sementara 
kebutuhan bisnis terdiri dari: kebutuhan perangkat keras, perangkat lunak dan infrastruktur yang diperlukan agar sistem dapat dijalankan dengan baik. Proses perencanaan juga meliputi pembagian proses pengembangan sistem menjadi sejumlah iterasi yang ditentukan berdasarkan prioritas fungsional sistem, serta penentuan pihak-pihak yang terlibat baik sebagai tim pengembang maupun pengguna sistem.

2) Perancangan

Perancangan dalam metodologi XP menggunakan prinsip KIS (Keep It Simple)[10], tidak terlalu rumit dan dalam waktu yang relatif singkat. Perancangan sistem dengan membuat diagram Use Case (UC) dan kartu CRC (CRC Cards). Menurut Rosa dan Shalahuddin[11] diagram UC merupakan pemodelan untuk kelakuan (behavior) sistem informasi. Sementara itu, kartu CRC[12] digunakan untuk mengidentifikasikan dan mengorganisasikan object-oriented classes.

3) Pembuatan Kode Program

Tahap ini merupakan tahap implementasi dari hasil rancangan menjadi bentuk antarmuka pengguna menggunakan bahasa pemrograman HTML, CSS, JavaScript, dan PHP dengan pendekatan pemrograman terstruktur. Framework Bootstrap 4 digunakan untuk mempermudah dalam pembuatan antarmuka pengguna dan MySQL Server digunakan untuk pengelolaan sistem basis data. Proses pembuatan kode program dilakukan dalam sejumlah tahapan djngan iterasi. Pengujian black box terhadap antarmuka yang dihasilkan dilakukan oleh sejumlah tester yang terdiri dari tim pengembang dan pengguna sistem, bertujuan untuk mendeteksi kesalahan-kesalahan (error) dan apakah hasilnya sudah sesuai dengan kebutuhan pengguna. Pengguna dapat memberikan masukan/usulan dalam bentuk feedback kepada tim pengembang untuk perbaikan sistem.

4) User Acceptance Test

Proses pengujian akhir dilakukan dengan membuat User Acceptance Test (UAT). Pengguna sistem diminta untuk mengisi formulir yang telah disediakan untuk memastikan kebutuhan pengguna telah terpenuhi.

\section{HASIL DAN PEMBAHASAN}

\section{A. Perencanaan}

Saat ini pelaksanaan proses administrasi peminjaman laptop untuk karyawan PT Gramedia dikelola oleh Bagian IT Operation yang berada dibawah Divisi Teknologi Informasi (TI).
Identifikasi permasalahan dari sistem peminjaman laptop saat ini adalah belum tersedianya sistem informasi berbasis komputer yang mengakibatkan:

1) Kesulitan dalam menelusuri ketersediaan laptop yang akan dipinjam.

2) Kesulitan menelusuri status keberadaan laptop.

3) Kesulitan dalam menelusuri riwayat peminjaman laptop.

4) Kesulitan dalam pembuatan laporan transaksi peminjaman yang diperlukan oleh manajemen.

5) Kesulitan dalam menyajikan data-data yang diperlukan oleh pihak manajemen dalam proses pengambilan keputusan.

6) Sering terjadi kesalahan pencatatan dan juga tidak dilakukannya pencatatan data transaksi oleh petugas administrasi.

Analisa kebutuhan pengguna dari sistem peminjaman laptop meliputi kebutuhan fungsional dan non fungsional sebagai berikut:

1) Kebutuhan fungsional terdiri dari:

a. Tersedianya fasilitas login untuk verifikasi pengguna aplikasi.

b. Tersedianya fitur untuk mengelola data laptop dan master data: merek, RAM, processor, hard disk dan sistem operasi.

c. Tersedianya fitur untuk mengelola transaksi peminjaman dan pengembalian laptop.

d. Tersedianya fitur untuk menampilkan dan mencetak laporan data transaksi peminjaman laptop untuk keperluan manajemen.

2) Kebutuhan non fungsional terdiri dari:

a. Aplikasi dapat diakses oleh aplikasi browser: Internet Explorer, Mozilla Firefox dan Google Chrome.

b. Tampilan aplikasi yang responsif menyesuaikan dengan ukuran layar perangkat yang digunakan.

c. Antarmuka aplikasi yang mudah digunakan oleh pengguna.

d. Aplikasi dapat diakses dengan cepat dan tidak membutuhkan sumber daya yang besar pada perangkat pengguna.

e. Penentuan kewenangan akses bagi pengguna admin dan superadmin. 
Berikut ini hasil dari analisa kebutuhan bisnis yang meliputi kebutuhan perangkat keras, perangkat lunak dan infrastruktur.

1) Kebutuhan perangkat keras meliputi:

a. Perangkat server dengan spesifikasi minimum: Prosesor $2 \mathrm{GHz}$ ), RAM 4 GB, Hard disk 500 GB, resolusi tampilan layar 800x600, perangkat untuk konkesi ke jaringan baik kabel atau nirkabel, sistem operasi Windows Server.

b. Perangkat client, dapat berupa:

- Perangkat laptop/PC dengan spesifikasi: Prosesor 1 gigahertz (GHz), RAM 2 GB, Hard disk $250 \mathrm{~GB}$, resolusi tampilan layar $800 \times 600$, perangkat untuk konkesi ke jaringan baik kabel atau nirkabel, sistem operasi Windows 7.

- Perangkat smartphone dengan spesifikasi:

Prosesor quad-core $1,2 \mathrm{GHz}$, sistem operasi Android 4.1 Jelly Bean, RAM 1GB, Internal Memory 8GB, layar 4 inci dengan resolusi 800x480, koneksi jaringan WiFi.

2) Kebutuhan perangkat lunak meliputi:

a. Perangkat lunak server, terdiri dari: Perangkat lunak server, terdiri dari: Apache 2.4, PHP 7.3, dan MySQL 5.

b. Perangkat lunak client berupa aplikasi browser, seperti: Internet Explorer, Mozilla Firefox dan Google Chrome.

3) Kebutuhan infrastruktur jaringan baik jaringan kabel atau nirkabel untuk mengakses web server.

Berikutnya adalah proses penentuan iterasi dalam proses pengembangan sistem menggunakan metode XP:

Tabel 1. Iterasi pengembangan sistem

\begin{tabular}{|c|c|c|c|}
\hline Iterasi & Pengguna & $\begin{array}{c}\text { Tim } \\
\text { Pengembang }\end{array}$ & Kegiatan \\
\hline \multirow[t]{6}{*}{1} & \multirow{6}{*}{$\begin{array}{l}\text { IT Operation } \\
\text { Manager, } \\
\text { IT Engineer, } \\
\text { Helpdesk } \\
\text { Superintendent, } \\
\text { Technician }\end{array}$} & \multirow[t]{6}{*}{$\begin{array}{c}\text { System } \\
\text { Analyst, } \\
\text { Programmer }\end{array}$} & $\begin{array}{l}\text { Pembuatan } \\
\text { template tampilan } \\
\text { halaman web }\end{array}$ \\
\hline & & & $\begin{array}{l}\text { Pembuatan login } \\
\text { sistem }\end{array}$ \\
\hline & & & $\begin{array}{l}\text { Pembuatan } \\
\text { fasilitas } \\
\text { pengelolaan } \\
\text { master data }\end{array}$ \\
\hline & & & $\begin{array}{l}\text { Pembuatan } \\
\text { fasilitas } \\
\text { pengelolaan data } \\
\text { karyawan sebagai } \\
\text { petugas } \\
\text { administrasi }\end{array}$ \\
\hline & & & $\begin{array}{l}\text { Pembuatan } \\
\text { fasilitas } \\
\text { pengelolaan data } \\
\text { laptop }\end{array}$ \\
\hline & & & Pembuatan menu \\
\hline
\end{tabular}

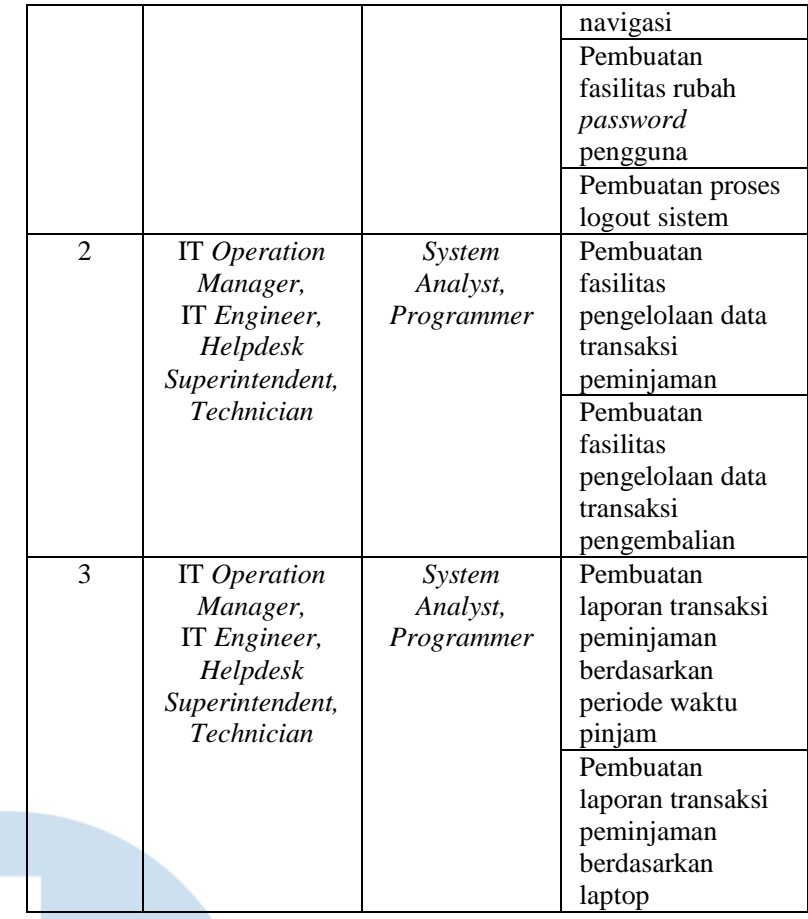

\section{B. Perancangan}

Diagram Use Case sistem dilihat pada Gambar 2 berikut:

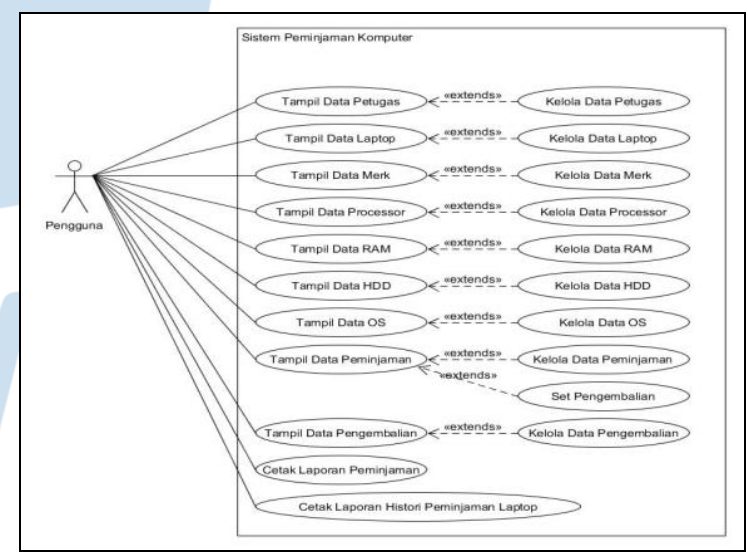

Gambar 2. Diagram Use Case 
Gambar 3 merupakan rancangan kartu CRC.

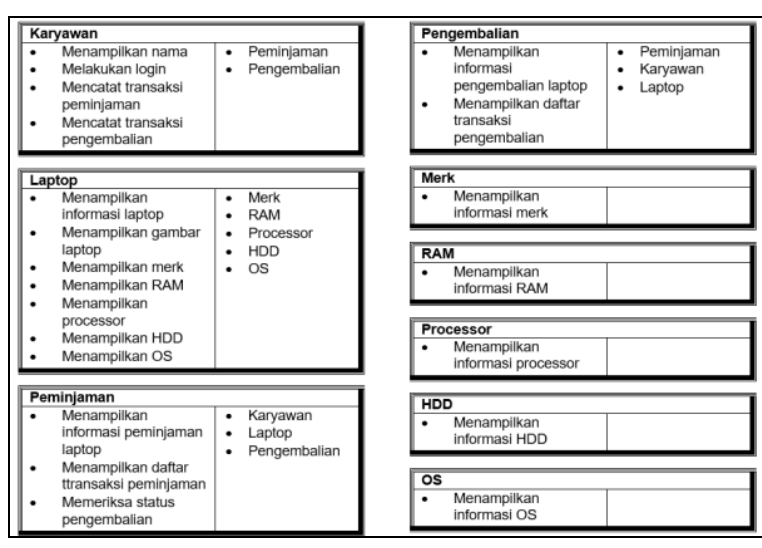

Gambar 3. Kartu CRC

\section{Pembuatan Kode Program}

Proses pengkodean sesuai dengan urutan iterasi yang telah ditentukan dalam tahap perencanaan.

1) Iterasi pertama meliputi proses pembuatan navigasi menu, halaman login pengguna, pengelolaan master data (terdiri dari data merk, processor, RAM, HDD dan sistem operasi (OS)) dan pengelolaan data laptop.

Tabel 2 berisi sejumlah feedback dan perbaikan yang terjadi pada tahapan iterasi pertama:

Tabel 2. Tabel feedback dan revisi iterasi pertama

\begin{tabular}{|l|l|}
\hline \multicolumn{1}{|c|}{ Feedback } & \multicolumn{1}{c|}{ Revisi yang dilakukan } \\
\hline $\begin{array}{l}\text { Penambahan fitur } \\
\text { 'Remember Me' pada } \\
\text { halaman login }\end{array}$ & $\begin{array}{l}\text { - Perubahan kode program } \\
\text { login pengguna. }\end{array}$ \\
\hline $\begin{array}{l}\text { Menambahkan fasilitas } \\
\text { disable/enable pada } \\
\text { fitur pengelolaan } \\
\text { master data }\end{array}$ & $\begin{array}{l}\text { - Penambahan kolom 'aktif' } \\
\text { pada struktur tabel HDD, } \\
\text { Merek, RAM, Processor, OS. } \\
\text { - Perubahan kode program } \\
\text { pengelolaan master data. }\end{array}$ \\
\hline $\begin{array}{l}\text { Mengganti gambar ikon } \\
\text { aplikasi }\end{array}$ & $\begin{array}{l}\text { - Membuat gambar ikon baru. } \\
\text { - Perubahan kode program } \\
\text { pada bagian navigasi. }\end{array}$ \\
\hline $\begin{array}{l}\text { Menambahkan fasilitas } \\
\text { filter pada tampiilan } \\
\text { tabel daftar laptop }\end{array}$ & $\begin{array}{l}\text { - Perubahan kode program } \\
\text { pengelolaan data laptop }\end{array}$ \\
\hline $\begin{array}{l}\text { Menambahkan } \\
\text { informasi nomor seri } \\
\text { laptop }\end{array}$ & $\begin{array}{l}\text { - Penambahan kolom 'no_seri' } \\
\text { pada struktur tabel } \\
\text { MDLaptop. }\end{array}$ \\
\hline
\end{tabular}

Berikut adalah struktur tabel basis data pada tahap iterasi ini:

Tabel 3. Struktur tabel karyawan

\begin{tabular}{|l|l|l|c|c|}
\hline \multicolumn{4}{|c|}{ Nama Tabel : Karyawan } & \multicolumn{1}{|c|}{ Tipe } \\
Atribut & Deskripsi & \multicolumn{1}{|c|}{ Null } & Unik \\
\hline $\begin{array}{l}\text { id_karya } \\
\text { wan }\end{array}$ & ID karyawan & int & Tidak & Ya \\
\hline nik & Nomor Induk & varchar & Tidak & Ya \\
\hline
\end{tabular}

\begin{tabular}{|l|l|l|c|c|}
\hline & Karyawan & $(10)$ & & \\
\hline nama & $\begin{array}{l}\text { Nama } \\
\text { karyawan }\end{array}$ & $\begin{array}{l}\text { varchar } \\
(100)\end{array}$ & Tidak & Tidak \\
\hline pass & $\begin{array}{l}\text { Password } \\
\text { login }\end{array}$ & $\begin{array}{l}\text { varchar } \\
(50)\end{array}$ & Tidak & Tidak \\
\hline aktif & Status aktif & char(1) & Tidak & Tidak \\
\hline
\end{tabular}

Tabel 4. Struktur tabel HDD

\begin{tabular}{|l|l|l|c|c|}
\hline \multicolumn{1}{|c|}{ Nama Tabel : HDD } \\
\hline Atribut & Deskripsi & Tipe Data & Null & Unik \\
\hline id_hdd & ID HDD & int & Tidak & Ya \\
\hline hdd & Nama HDD & $\begin{array}{l}\text { varchar } \\
(255)\end{array}$ & Tidak & Ya \\
\hline aktif & Status aktif & char(1) & Tidak & Tidak \\
\hline
\end{tabular}

Tabel 5. Struktur tabel merek

\begin{tabular}{|l|l|l|c|c|}
\hline \multicolumn{5}{|c|}{ Nama Tabel : Merk } \\
\hline Atribut & Deskripsi & Tipe Data & Null & Unik \\
\hline id_merk & ID merk & int & Tidak & Ya \\
\hline merk & $\begin{array}{l}\text { Nama } \\
\text { merek }\end{array}$ & $\begin{array}{l}\text { varchar } \\
(255)\end{array}$ & Tidak & Ya \\
\hline aktif & Status aktif & char(1) & Tidak & Tidak \\
\hline
\end{tabular}

Tabel 6. Struktur tabel RAM

\begin{tabular}{|l|l|l|c|c|}
\hline \multicolumn{1}{|l|}{ Nama Tabel : RAM } \\
\hline Atribut & Deskripsi & \multicolumn{1}{|l|}{ Tipe Data } & Null & Unik \\
\hline id_ram & ID RAM & int & Tidak & Ya \\
\hline ram & Nama RAM & $\begin{array}{l}\text { varchar } \\
(255)\end{array}$ & Tidak & Ya \\
\hline aktif & Status aktif & char(1) & Tidak & Tidak \\
\hline
\end{tabular}

Tabel 7. Struktur tabel processor

\begin{tabular}{|l|l|l|c|c|}
\hline \multicolumn{4}{|l|}{ Nama Tabel : Processor } \\
\hline \multicolumn{1}{|c|}{ Atribut } & \multicolumn{1}{|l|}{ Deskripsi } & Tipe Data & Null & Unik \\
\hline $\begin{array}{l}\text { id_process } \\
\text { or }\end{array}$ & ID processor & int & Tidak & Ya \\
\hline processor & $\begin{array}{l}\text { Nama } \\
\text { processor }\end{array}$ & varchar (255) & Tidak & Ya \\
\hline aktif & Status aktif & char(1) & Tidak & Tidak \\
\hline
\end{tabular}

Tabel 8. Struktur tabel OS

\begin{tabular}{|l|l|l|c|c|}
\hline \multicolumn{5}{|l|}{ Nama Tabel : OS } \\
\hline Atribut & \multicolumn{1}{|c|}{ Deskripsi } & Tipe Data & Null & Unik \\
\hline id_os & $\begin{array}{l}\text { ID sistem } \\
\text { operasi }\end{array}$ & int & Tidak & Ya \\
\hline os & Sistem operasi & varchar (255) & Tidak & Ya \\
\hline aktif & Status aktif & char(1) & Tidak & Tidak \\
\hline
\end{tabular}

Tabel 9. Struktur tabel MDLaptop

\begin{tabular}{|l|l|l|c|c|}
\hline Nama Tabel : MDLaptop & \multicolumn{4}{|c|}{} \\
\hline Atribut & Deskripsi & Tipe Data & $\begin{array}{c}\text { Nilai } \\
\text { Null }\end{array}$ & $\begin{array}{c}\text { Nilai } \\
\text { Unik }\end{array}$ \\
\hline id_laptop & ID Laptop & int & Tidak & Y \\
\hline no_seri & No seri laptop & $\begin{array}{l}\text { varchar } \\
(50)\end{array}$ & Tidak & Ya \\
\hline nama_laptop & Nama laptop & varchar & Tidak & Ya \\
\hline
\end{tabular}




\begin{tabular}{|c|c|c|c|c|c|c|}
\hline & & & \multicolumn{2}{|l|}{ (255) } & & \\
\hline id_merk & \multicolumn{2}{|l|}{ ID merek } & \multicolumn{2}{|l|}{ int } & Tidak & Tidak \\
\hline id_processor & \multicolumn{2}{|l|}{ ID processor } & \multicolumn{2}{|l|}{ int } & Tidak & Tidak \\
\hline id_ram & \multicolumn{2}{|l|}{ ID RAM } & \multicolumn{2}{|l|}{ int } & Tidak & Tidak \\
\hline id_hdd & \multicolumn{2}{|l|}{ ID HDD } & \multicolumn{2}{|l|}{ int } & Tidak & Tidak \\
\hline id_os & \multicolumn{2}{|l|}{ ID OS } & \multicolumn{2}{|l|}{ int } & Tidak & Tidak \\
\hline bluetooth & \multicolumn{2}{|l|}{ Bluetooth } & \multicolumn{2}{|c|}{ varchar (5) } & Tidak & Tidak \\
\hline vga_port & \multicolumn{2}{|l|}{ Port VGA } & \multicolumn{2}{|c|}{ varchar (5) } & Tidak & Tidak \\
\hline hdmi & \multicolumn{2}{|c|}{ Port HDMI } & \multicolumn{2}{|c|}{ varchar (5) } & Tidak & Tidak \\
\hline display & \multicolumn{2}{|c|}{$\begin{array}{l}\text { Ukuran } \\
\text { display dalam } \\
\text { inci }\end{array}$} & \multicolumn{2}{|c|}{ varchar (5) } & Tidak & Tidak \\
\hline keterangan & \multicolumn{2}{|c|}{ Keterangan } & \multicolumn{2}{|c|}{$\begin{array}{l}\text { varchar } \\
(255)\end{array}$} & Tidak & Tidak \\
\hline foto & \multicolumn{2}{|l|}{$\begin{array}{l}\text { Lokasi file } \\
\text { foto }\end{array}$} & \multicolumn{2}{|c|}{$\begin{array}{l}\text { varchar } \\
(255)\end{array}$} & Tidak & Tidak \\
\hline status & \multicolumn{2}{|l|}{ Status } & varcha & $(5)$ & Tidak & Tidak \\
\hline & & deks & Tabel & & & \\
\hline Nama & Nama & & Jenis & & RefeI & rensi \\
\hline Indeks & Kolom & & ideks & Ta & bel & \begin{tabular}{|l|} 
Kolom \\
\end{tabular} \\
\hline $\begin{array}{l}\text { fk_mdlaptop } \\
\text { _merk }\end{array}$ & id_merk & $\begin{array}{l}\text { For } \\
\text { Key }\end{array}$ & reign & Merk & & id_merk \\
\hline $\begin{array}{l}\text { fk_mdlaptop } \\
\text { _processor }\end{array}$ & $\begin{array}{l}\text { id_proces } \\
\text { sor }\end{array}$ & & $\begin{array}{l}\text { reign } \\
y\end{array}$ & Proce & essor & $\begin{array}{l}d_{-} \\
\text {processor }\end{array}$ \\
\hline $\begin{array}{l}\text { fk_mdlaptop } \\
\text { _ram }\end{array}$ & id_ram & $\begin{array}{l}\text { For } \\
\text { Key }\end{array}$ & $\begin{array}{l}\text { reign } \\
y\end{array}$ & RAM & & id_ram \\
\hline $\begin{array}{l}\text { fk_mdlaptop } \\
\text { hdd }\end{array}$ & id_hdd & $\begin{array}{l}\text { For } \\
\text { Key }\end{array}$ & $\begin{array}{l}\text { reign } \\
y\end{array}$ & HDD & & id_hdd \\
\hline $\begin{array}{l}\text { fk_mdlaptop } \\
\text { _os }\end{array}$ & id_os & $\begin{array}{l}\text { For } \\
\text { Key }\end{array}$ & $\begin{array}{l}\text { reign } \\
y\end{array}$ & OS & & id_os \\
\hline
\end{tabular}

Penggunaan framework Bootstrap dilakukan dengan menghubungkan kode program yang dibuat dengan CSS dan JavaScript Bootstrap melalui layanan Content Delivery Network (CDN).

Untuk menghubungan kode program dengan CSS Bootstrap dilakukan dengan menambahkan baris berikut pada tag <head> [13]:

\section{$<$ link rel="stylesheet"}

href="https://maxcdn.bootstrapcdn.com/bootstr ap/4.0.0/css/bootstrap.min.css"

integrity $="$ sha384-

Gn5384xqQ1aoWXA+058RXPxPg6fy4IWvTNhO E263XmFcJlSAwiGgFAW/dAiS6JXm"

crossorigin = "anonymous" $>$

Untuk menghubungan kode program dengan JavaScript Bootstrap dilakukan dengan menambahkan baris berikut pada tag <body $>$ [13]:

< script src="https://code.jquery.com/jquery-

3.2.1.slim.min.js" integrity= "sha384-

KJ3o2DKtIkvYIK3UENzmM7KCkRr/rE9/Qpg6a AZGJwFDMVNA/GpGFF93hXpG5KkN"

crossorigin = "anonymous" $></$ script $>$

$<$ script

src="https://cdnjs.cloudflare.com/ajax/libs/popp er.js/1.12.9/umd/popper.min.js"

integrity $="$ sha384-

ApNbgh9B+Y1QKtv3Rn7W3mgPxhU9K/ScQsA
P7hUibX39j7fakFPskvXusvfa0b4Q"

crossorigin="anonymous" $>\langle/$ script $>$

$<$ script

src $="$ "https://maxcdn.bootstrapcdn.com/bootstra p/4.0.0/js/bootstrap.min.js" integrity="sha384JZR6Spejh4U02d8jOt6vLEHfe/JQGiRRSQQxSf FWpilMquVdAyjUar5+76PVCmYl"

crossorigin = "anonymous" $\rangle\langle/$ script $\rangle$

Berikut ini adalah tampilan aplikasi pada akhir tahap iterasi pertama.

Halaman Login Pengguna digunakan untuk melakukan proses verifikasi pengguna aplikasi.

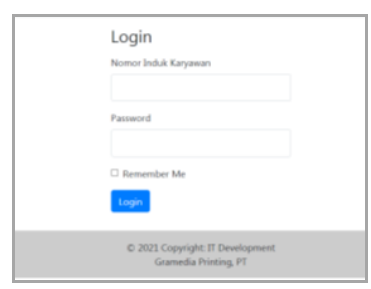

Gambar 4. Tampilan halaman login

Menu Navigasi digunakan untuk menampilkan sejumlah link untuk berpindah halaman.

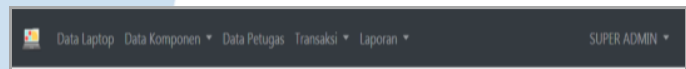

Gambar 5. Tampilan menu navigasi

Halaman Data Laptop digunakan untuk menampilkan dan mengelola data laptop yang dapat dipinjam.

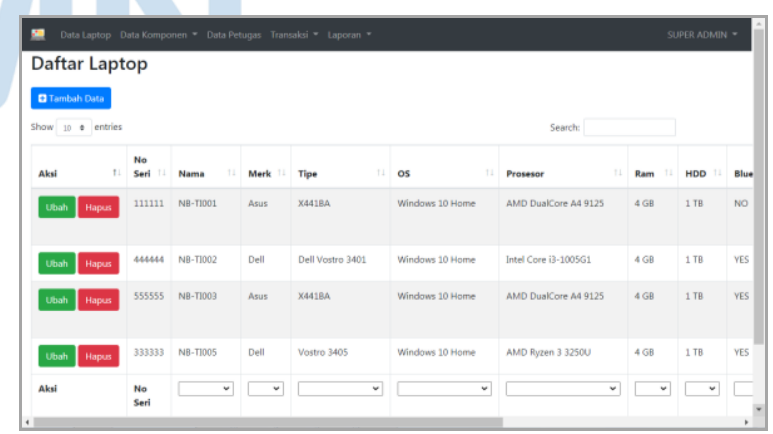

Gambar 6. Tampilan halaman data laptop

Halaman Data Merk digunakan untuk menampilkan dan mengelola data merek. 


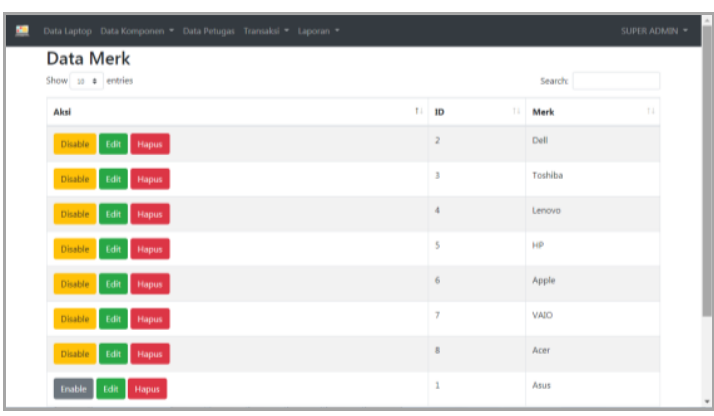

Gambar 7. Tampilan halaman data merk

Halaman Data Processor digunakan untuk menampilkan dan mengelola data processor.

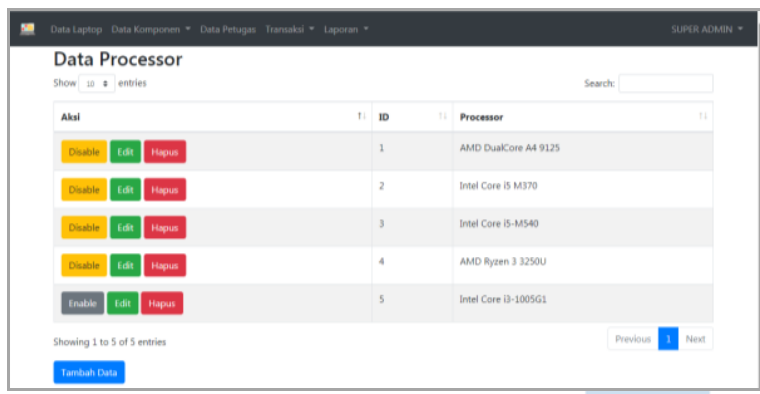

Gambar 8. Tampilan halaman data processor

Halaman Data RAM digunakan untuk menampilkan dan mengelola data RAM.

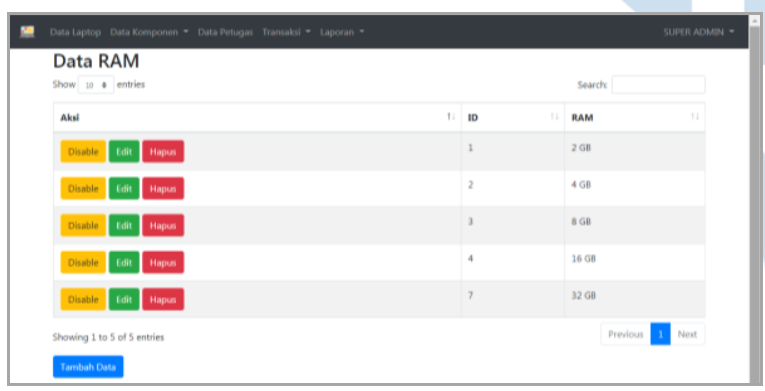

Gambar 9. Tampilan halaman data RAM

Halaman Data HDD digunakan untuk menampilkan dan mengelola data HDD.

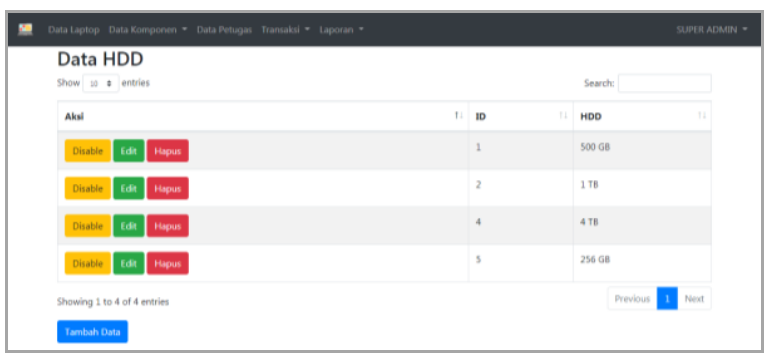

Gambar 10. Tampilan halaman data HDD
Halaman Data OS digunakan untuk menampilkan dan mengelola data OS

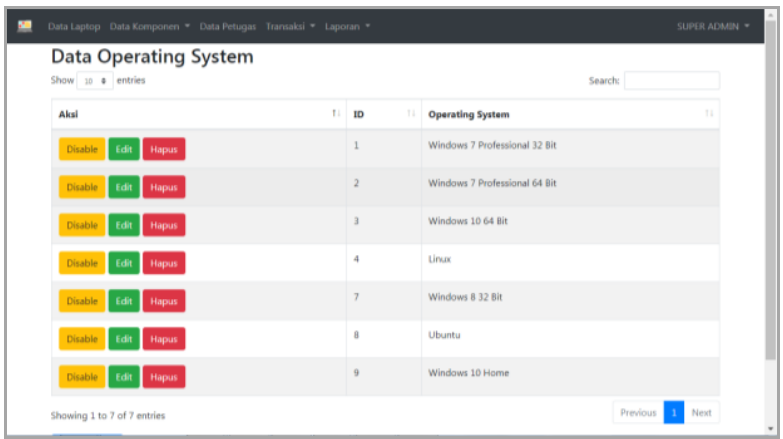

Gambar 11. Tampilan halaman data OS

Halaman Data Petugas digunakan untuk menampilkan dan mengelola data petugas administrasi peminjaman laptop.

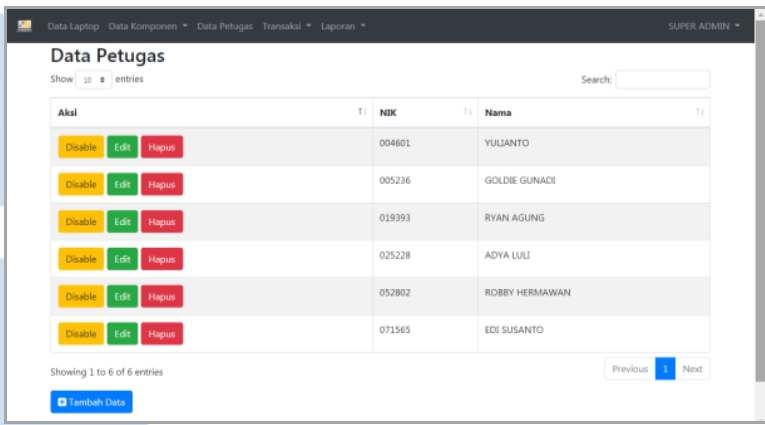

Gambar 12. Tampilan halaman data petugas

Hasil pengujian black box untuk memastikan fungsional aplikasi pada tahap iterasi pertama telah terpenuhi.

Hasil pengujian antarmuka halaman Login:

Tabel 10. Hasil pengujian antarmuka halaman login

\begin{tabular}{|c|c|c|c|}
\hline $\begin{array}{c}\text { Kegiatan } \\
\text { Pengujian }\end{array}$ & $\begin{array}{c}\text { Hasil yang } \\
\text { Diharapkan }\end{array}$ & $\begin{array}{c}\text { Hasil } \\
\text { Pengujian }\end{array}$ & Kesimpulan \\
\hline $\begin{array}{l}\text { Melakukan } \\
\text { proses } \\
\text { login }\end{array}$ & $\begin{array}{l}\text { Apabila } \\
\text { verifikasi } \\
\text { benar akan } \\
\text { masuk ke } \\
\text { halaman } \\
\text { 'Daftar } \\
\text { Laptop' } \\
\text { Apabila } \\
\text { verifikasi } \\
\text { salah akan } \\
\text { menampilkan } \\
\text { pesan } \\
\text { kesalahan }\end{array}$ & $\begin{array}{l}\text { Menampilkan } \\
\text { halaman Data } \\
\text { Laptop pada } \\
\text { saat login } \\
\text { sukses. } \\
\text { Menampilkan } \\
\text { pesan } \\
\text { kesalahan } \\
\text { pada saat } \\
\text { login gagal. }\end{array}$ & Sukses \\
\hline $\begin{array}{l}\text { Mengaktif- } \\
\text { kan opsi } \\
\text { 'Remember } \\
M e \text { ' }\end{array}$ & $\begin{array}{l}\text { Data login } \\
\text { pengguna } \\
\text { tersimpan di } \\
\text { lokal sehingga } \\
\text { pengguna } \\
\text { tidak perlu }\end{array}$ & $\begin{array}{l}\text { Data login } \\
\text { pengguna } \\
\text { tersimpan di } \\
\text { computer } \\
\text { lokal dalam } \\
\text { bentuk cookie. }\end{array}$ & Sukses \\
\hline
\end{tabular}




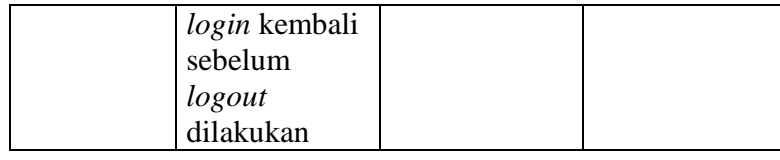

Hasil pengujian antarmuka halaman Data Laptop:

Tabel 11. Hasil pengujian antarmuka halaman data laptop

\begin{tabular}{|c|c|c|c|}
\hline $\begin{array}{c}\text { Kegiatan } \\
\text { Pengujian }\end{array}$ & $\begin{array}{c}\text { Hasil yang } \\
\text { Diharapkan }\end{array}$ & $\begin{array}{c}\text { Hasil } \\
\text { Pengujian }\end{array}$ & Kesimpulan \\
\hline $\begin{array}{l}\text { Menampil- } \\
\text { kan daftar } \\
\text { laptop } \\
\text { yang ada. }\end{array}$ & $\begin{array}{l}\text { Sistem } \\
\text { menampilkan } \\
\text { seluruh data } \\
\text { laptop yang } \\
\text { tersimpan } \\
\text { dalam basis } \\
\text { data. }\end{array}$ & $\begin{array}{l}\text { Seluruh data } \\
\text { laptop } \\
\text { ditampilkan. }\end{array}$ & Sukses \\
\hline $\begin{array}{l}\text { Menambah } \\
\text { data laptop } \\
\text { baru. }\end{array}$ & $\begin{array}{l}\text { Sistem } \\
\text { menampilkan } \\
\text { form input } \\
\text { data laptop. } \\
\text { Sistem } \\
\text { menyimpan } \\
\text { data laptop } \\
\text { baru ke dalam } \\
\text { basis data. }\end{array}$ & $\begin{array}{l}\text { Form input } \\
\text { ditampilkan. } \\
\text { Data laptop } \\
\text { baru berhasil } \\
\text { disimpan dalam } \\
\text { basis data. }\end{array}$ & Sukses \\
\hline $\begin{array}{l}\text { Merubah } \\
\text { data laptop. }\end{array}$ & $\begin{array}{l}\text { Sistem } \\
\text { menampilkan } \\
\text { form edit data } \\
\text { laptop. } \\
\text { Sistem } \\
\text { menyimpan } \\
\text { perubahan } \\
\text { data laptop } \\
\text { pada basis } \\
\text { data. }\end{array}$ & $\begin{array}{l}\text { Form edit } \\
\text { ditampilkan. } \\
\text { Perubahan data } \\
\text { laptop berhasil } \\
\text { disimpan pada } \\
\text { basis data. }\end{array}$ & Sukses \\
\hline $\begin{array}{l}\text { Menghapus } \\
\text { data laptop. }\end{array}$ & $\begin{array}{l}\text { Sistem } \\
\text { menampilkan } \\
\text { permintaan } \\
\text { konfirmasi } \\
\text { hapus data. } \\
\text { Sistem } \\
\text { menghapus } \\
\text { data laptop } \\
\text { dari basis } \\
\text { data. }\end{array}$ & $\begin{array}{l}\text { Permintaan } \\
\text { konfirmasi } \\
\text { ditampilkan. } \\
\text { Data laptop } \\
\text { berhasil } \\
\text { dihapus dari } \\
\text { basis data. }\end{array}$ & Sukses \\
\hline
\end{tabular}

Hasil pengujian antarmuka halaman Data Merk/ Processor/ RAM/ HDD/ OS:

Tabel 12. Hasil pengujian antarmuka halaman data merk/ processor/ RAM/ HDD/ OS

\begin{tabular}{|l|l|l|l|}
\hline $\begin{array}{c}\text { Kegiatan } \\
\text { Pengujian }\end{array}$ & \multicolumn{1}{|c|}{$\begin{array}{c}\text { Hasil yang } \\
\text { Diharapkan }\end{array}$} & $\begin{array}{c}\text { Hasil } \\
\text { Pengujian }\end{array}$ & Kesimpulan \\
\hline $\begin{array}{l}\text { Menampil- } \\
\text { kan daftar } \\
\text { data yang } \\
\text { ada. }\end{array}$ & $\begin{array}{l}\text { Sistem } \\
\text { menampilkan } \\
\text { seluruh data } \\
\text { yang }\end{array}$ & $\begin{array}{l}\text { Seluruh data } \\
\text { ditampilkan. }\end{array}$ & Sukses \\
& tersimpan & & \\
& dalam basis & & \\
& data. & & \\
\hline Menambah & Sistem & Form input & Sukses \\
\hline
\end{tabular}

\begin{tabular}{|c|c|c|c|}
\hline data baru. & \begin{tabular}{|l|} 
menampilkan \\
form input \\
data. \\
Sistem \\
menyimpan \\
data baru ke \\
dalam basis \\
data. \\
\end{tabular} & $\begin{array}{l}\text { ditampilkan. } \\
\text { Data baru } \\
\text { berhasil } \\
\text { disimpan } \\
\text { dalam basis } \\
\text { data. }\end{array}$ & \\
\hline $\begin{array}{l}\text { Merubah } \\
\text { data. }\end{array}$ & \begin{tabular}{|l} 
Sistem \\
menampilkan \\
form edit data. \\
Sistem \\
menyimpan \\
perubahan \\
data pada \\
basis data.
\end{tabular} & $\begin{array}{l}\text { Form edit } \\
\text { ditampilkan. } \\
\text { Perubahan } \\
\text { data berhasil } \\
\text { disimpan pada } \\
\text { basis data. }\end{array}$ & Sukses \\
\hline $\begin{array}{l}\text { Menghapus } \\
\text { data. }\end{array}$ & \begin{tabular}{|l} 
Sistem \\
menampilkan \\
permintaan \\
konfirmasi \\
hapus data. \\
Sistem \\
menghapus \\
data dari basis \\
data.
\end{tabular} & \begin{tabular}{|l} 
Permintaan \\
konfirmasi \\
ditampilkan. \\
Data berhasil \\
dihapus dari \\
basis data.
\end{tabular} & Sukses \\
\hline $\begin{array}{l}\text { Merubah } \\
\text { status data } \\
\text { menjadi } \\
\text { Aktif } \\
\text { menjadi } \\
\text { Tidak Aktif } \\
\text { dan } \\
\text { sebaliknya }\end{array}$ & $\begin{array}{l}\text { Sistem } \\
\text { menampilkan } \\
\text { permintaan } \\
\text { konfirmasi } \\
\text { rubah status } \\
\text { data. } \\
\text { Sistem } \\
\text { menyimpan } \\
\text { perubahan } \\
\text { status data } \\
\text { pada basis } \\
\text { data. }\end{array}$ & \begin{tabular}{|l} 
Permintaan \\
konfirmasi \\
ditampilkan. \\
Status data \\
pada basis \\
data berhasil \\
dirubah.
\end{tabular} & Sukses \\
\hline
\end{tabular}

Hasil pengujian antarmuka halaman Data Petugas:

Tabel 13. Hasil pengujian antarmuka halaman data petugas

\begin{tabular}{|c|c|c|c|}
\hline $\begin{array}{c}\text { Kegiatan } \\
\text { Pengujian }\end{array}$ & $\begin{array}{c}\text { Hasil yang } \\
\text { Diharapkan }\end{array}$ & $\begin{array}{c}\text { Hasil } \\
\text { Pengujian }\end{array}$ & Kesimpulan \\
\hline $\begin{array}{l}\text { Menampil- } \\
\text { kan daftar } \\
\text { petugas } \\
\text { yang ada. }\end{array}$ & $\begin{array}{l}\text { Sistem } \\
\text { menampilkan } \\
\text { seluruh data } \\
\text { petugas yang } \\
\text { tersimpan dalam } \\
\text { basis data. }\end{array}$ & $\begin{array}{l}\text { Seluruh } \\
\text { data } \\
\text { petugas } \\
\text { ditampilkan } \\
\text {. }\end{array}$ & Sukses \\
\hline $\begin{array}{l}\text { Menambah } \\
\text { data } \\
\text { petugas } \\
\text { baru. }\end{array}$ & $\begin{array}{l}\text { Sistem } \\
\text { menampilkan } \\
\text { form input data } \\
\text { petugas. } \\
\text { Sistem } \\
\text { menyimpan data } \\
\text { petugas baru ke } \\
\text { dalam basis data. }\end{array}$ & $\begin{array}{l}\text { Form input } \\
\text { ditampilkan } \\
\text { Data } \\
\text { petugas } \\
\text { baru } \\
\text { berhasil } \\
\text { disimpan } \\
\text { dalam basis } \\
\text { data. }\end{array}$ & Sukses \\
\hline $\begin{array}{l}\text { Merubah } \\
\text { data } \\
\text { petugas. }\end{array}$ & $\begin{array}{l}\text { Sistem } \\
\text { menampilkan } \\
\text { form edit data } \\
\text { petugas. }\end{array}$ & $\begin{array}{l}\text { Form edit } \\
\text { ditampilkan } \\
\text { Perubahan }\end{array}$ & Sukses \\
\hline
\end{tabular}




\begin{tabular}{|c|c|c|c|}
\hline & $\begin{array}{l}\text { Sistem } \\
\text { menyimpan } \\
\text { perubahan data } \\
\text { petugas pada } \\
\text { basis data. }\end{array}$ & $\begin{array}{l}\text { data } \\
\text { petugas } \\
\text { berhasil } \\
\text { disimpan } \\
\text { pada basis } \\
\text { data. }\end{array}$ & \\
\hline $\begin{array}{l}\text { Menghapus } \\
\text { data } \\
\text { petugas. }\end{array}$ & $\begin{array}{l}\text { Sistem } \\
\text { menampilkan } \\
\text { permintaan } \\
\text { konfirmasi } \\
\text { hapus data } \\
\text { petugas. } \\
\text { Sistem } \\
\text { menghapus data } \\
\text { petugas dari } \\
\text { basis data. } \\
\end{array}$ & $\begin{array}{l}\text { Permintaan } \\
\text { konfirmasi } \\
\text { ditampilkan } \\
\text { Data } \\
\text { petugas } \\
\text { berhasil } \\
\text { dihapus } \\
\text { dari basis } \\
\text { data. } \\
\end{array}$ & Sukses \\
\hline $\begin{array}{l}\text { Merubah } \\
\text { status data } \\
\text { petugas } \\
\text { menjadi } \\
\text { Aktif } \\
\text { menjadi } \\
\text { Tidak Aktif } \\
\text { dan } \\
\text { sebaliknya }\end{array}$ & $\begin{array}{l}\text { Sistem } \\
\text { menampilkan } \\
\text { permintaan } \\
\text { konfirmasi rubah } \\
\text { status data } \\
\text { petugas. } \\
\text { Sistem } \\
\text { menyimpan } \\
\text { perubahan status } \\
\text { data petugas } \\
\text { pada basis data. }\end{array}$ & $\begin{array}{l}\text { Permintaan } \\
\text { konfirmasi } \\
\text { ditampilkan } \\
\text { Status data } \\
\text { petugas } \\
\text { pada basis } \\
\text { data } \\
\text { berhasil } \\
\text { dirubah. }\end{array}$ & Sukses \\
\hline
\end{tabular}

Hasil pengujian menu navigasi:

Tabel 14. Hasil pengujian menu navigasi

\begin{tabular}{|c|c|c|c|}
\hline $\begin{array}{c}\text { Kegiatan } \\
\text { Pengujian } \\
\end{array}$ & $\begin{array}{c}\text { Hasil yang } \\
\text { Diharapkan }\end{array}$ & $\begin{array}{c}\text { Hasil } \\
\text { Pengujian }\end{array}$ & $\begin{array}{l}\text { Kesim- } \\
\text { pulan }\end{array}$ \\
\hline $\begin{array}{l}\text { Memilih menu } \\
\text { Data Laptop. }\end{array}$ & $\begin{array}{l}\text { Menampilkan } \\
\text { halaman Data } \\
\text { Laptop. }\end{array}$ & $\begin{array}{l}\text { Halaman } \\
\text { Data Laptop } \\
\text { ditampilkan. }\end{array}$ & Sukses \\
\hline $\begin{array}{l}\text { Memilih menu } \\
\text { Data Merk. }\end{array}$ & $\begin{array}{l}\text { Menampilkan } \\
\text { halaman Data } \\
\text { Merk. }\end{array}$ & $\begin{array}{l}\text { Halaman } \\
\text { Data Merk } \\
\text { ditampilkan. }\end{array}$ & Sukses \\
\hline $\begin{array}{l}\text { Memilih menu } \\
\text { Data } \\
\text { Processor. }\end{array}$ & $\begin{array}{l}\text { Menampilkan } \\
\text { halaman Data } \\
\text { Processor. }\end{array}$ & $\begin{array}{l}\text { Halaman } \\
\text { Data } \\
\text { Processor } \\
\text { ditampilkan. }\end{array}$ & Sukses \\
\hline $\begin{array}{l}\text { Memilih menu } \\
\text { Data RAM. }\end{array}$ & $\begin{array}{l}\text { Menampilkan } \\
\text { halaman Data } \\
\text { RAM. }\end{array}$ & $\begin{array}{l}\text { Halaman } \\
\text { Data RAM } \\
\text { ditampilkan. }\end{array}$ & Sukses \\
\hline $\begin{array}{l}\text { Memilih menu } \\
\text { Data HDD. }\end{array}$ & $\begin{array}{l}\text { Menampilkan } \\
\text { halaman Data } \\
\text { HDD. }\end{array}$ & $\begin{array}{l}\text { Halaman } \\
\text { Data HDD } \\
\text { ditampilkan. }\end{array}$ & Sukses \\
\hline $\begin{array}{l}\text { Memilih menu } \\
\text { Data } \\
\text { Operating } \\
\text { System. }\end{array}$ & \begin{tabular}{|l|} 
Menampilkan \\
halaman Data \\
Operating \\
System. \\
\end{tabular} & $\begin{array}{l}\text { Halaman } \\
\text { Data OS } \\
\text { ditampilkan. }\end{array}$ & Sukses \\
\hline $\begin{array}{l}\text { Memilih menu } \\
\text { Data Petugas. }\end{array}$ & $\begin{array}{l}\text { Menampilkan } \\
\text { halaman Data } \\
\text { Petugas. } \\
\end{array}$ & $\begin{array}{l}\text { Halaman } \\
\text { Data Petugas } \\
\text { ditampilkan. }\end{array}$ & Sukses \\
\hline $\begin{array}{l}\text { Merubah } \\
\text { Password } \\
\text { Pengguna. }\end{array}$ & \begin{tabular}{|l|} 
Sistem \\
menampilkan \\
form rubah \\
password \\
pengguna. \\
Sistem \\
menyimpan \\
perubahan \\
password \\
\end{tabular} & $\begin{array}{l}\text { Form rubah } \\
\text { password } \\
\text { ditampilkan. } \\
\text { Perubahan } \\
\text { password } \\
\text { pengguna } \\
\text { berhasil } \\
\text { disimpan } \\
\text { pada basis } \\
\end{array}$ & Sukses \\
\hline
\end{tabular}

\begin{tabular}{|l|l|l|l|}
\hline & $\begin{array}{l}\text { pengguna pada } \\
\text { basis data. }\end{array}$ & data. & \\
\hline $\begin{array}{l}\text { Logout dari } \\
\text { sistem. }\end{array}$ & $\begin{array}{l}\text { Proses logout } \\
\text { dilakukan. }\end{array}$ & $\begin{array}{l}\text { Proses logout } \\
\text { berhasil } \\
\text { dilakukan dan }\end{array}$ & Sukses \\
& $\begin{array}{l}\text { Sistem } \\
\text { menampilkan } \\
\text { halaman Login. }\end{array}$ & $\begin{array}{l}\text { sistem } \\
\text { menampilkan } \\
\text { halaman }\end{array}$ & \\
& & Login. & \\
\hline
\end{tabular}

2) Iterasi kedua meliputi proses pembuatan halaman pengelolaan transaksi peminjaman dan pengembalian laptop.

Tabel 15 berisi sejumlah feedback dan perbaikan yang terjadi pada tahapan iterasi kedua.

Tabel 9. Tabel feedback dan revisi iterasi kedua

\begin{tabular}{|c|c|}
\hline Feedback & Revisi yang dilakukan \\
\hline $\begin{array}{l}\text { Menampilkan warna } \\
\text { background merah pada kolom } \\
\text { 'Rencana Kembali' dalam tabel } \\
\text { daftar peminjaman laptop } \\
\text { apabila tanggal rencana } \\
\text { kembali telah lewat dari } \\
\text { tanggal hari ini. }\end{array}$ & $\begin{array}{l}\text { - Perubahan kode } \\
\text { program pengelolaan } \\
\text { transaksi peminjaman } \\
\text { laptop. }\end{array}$ \\
\hline $\begin{array}{l}\text { Menggabungkan kolom 'Merk' } \\
\text { dan 'Tipe' menjadi } 1 \text { kolom } \\
\text { 'Merk/Tipe' pada tabel daftar } \\
\text { peminjaman laptop. }\end{array}$ & $\begin{array}{l}\text { - Perubahan kode } \\
\text { program pengelolaan } \\
\text { transaksi peminjaman } \\
\text { laptop. }\end{array}$ \\
\hline $\begin{array}{l}\text { Menggabungkan kolom 'Merk' } \\
\text { dan 'Tipe' menjadi } 1 \text { kolom } \\
\text { 'Merk/Tipe' pada tabel daftar } \\
\text { pengembalian laptop. }\end{array}$ & $\begin{array}{l}\text { Perubahan kode } \\
\text { program pengelolaan } \\
\text { transaksi } \\
\text { pengembalian laptop. }\end{array}$ \\
\hline
\end{tabular}

Struktur tabel basis data pada akhir tahap iterasi ini:

Tabel 16. Atribut entitas peminjaman

\begin{tabular}{|l|l|l|c|c|}
\hline \multicolumn{1}{|c|}{ Atribut } & \multicolumn{1}{|c|}{ Deskripsi } & Tipe Data & Null & Unik \\
\hline id_peminjaman & $\begin{array}{l}\text { ID } \\
\text { peminjaman }\end{array}$ & varchar (9) & Tidak & Ya \\
\hline tanggal_pinjam & $\begin{array}{l}\text { Tanggal } \\
\text { pinjam }\end{array}$ & datetime & Tidak & Tidak \\
\hline admin_pinjam & $\begin{array}{l}\text { ID petugas } \\
\text { admin } \\
\text { peminjaman }\end{array}$ & int & Tidak & Tidak \\
\hline peminjam & $\begin{array}{l}\text { Nama } \\
\text { peminjam }\end{array}$ & $\begin{array}{l}\text { varchar } \\
(255)\end{array}$ & Tidak & Tidak \\
\hline id_laptop & ID laptop & int & Tidak & Tidak \\
\hline keperluan & $\begin{array}{l}\text { Keperluan } \\
\text { varchar } \\
(255)\end{array}$ & Tidak & Tidak \\
\hline $\begin{array}{l}\text { kelengkapan_ } \\
\text { pinjam }\end{array}$ & $\begin{array}{l}\text { Kelengkapan } \\
\text { saat pinjam }\end{array}$ & $\begin{array}{l}\text { varchar } \\
(255)\end{array}$ & Tidak & Tidak \\
\hline catatan_pinjam & $\begin{array}{l}\text { Catatan } \\
\text { varchar } \\
(255)\end{array}$ & Tidak & Tidak \\
\hline $\begin{array}{l}\text { rencana_ } \\
\text { kembali }\end{array}$ & $\begin{array}{l}\text { Tanggal } \\
\text { perkiraan } \\
\text { kembali }\end{array}$ & datetime & Tidak & Tidak \\
\hline $\begin{array}{l}\text { tanggal_- } \\
\text { kembali }\end{array}$ & $\begin{array}{l}\text { Tanggal } \\
\text { kembali }\end{array}$ & $\begin{array}{l}\text { datetime } \\
\text { admin } \\
\text { peminjaman }\end{array}$ & Ya & Tidak \\
\hline admin_kembali & $\begin{array}{l}\text { ID petugas } \\
\text { int }\end{array}$ & Ya & Tidak \\
\hline
\end{tabular}




\begin{tabular}{|c|c|c|c|c|c|c|}
\hline pengembali & \multicolumn{2}{|c|}{$\begin{array}{l}\text { Nama } \\
\text { pengembali }\end{array}$} & \multicolumn{2}{|c|}{\begin{tabular}{|l} 
varchar \\
$(255)$
\end{tabular}} & $\mathrm{Ya}$ & Tidak \\
\hline $\begin{array}{l}\text { kelengkapan } \\
\text { kembali }\end{array}$ & \multicolumn{2}{|c|}{$\begin{array}{l}\text { Kelengkapan } \\
\text { saat kembali }\end{array}$} & \multicolumn{2}{|c|}{$\begin{array}{l}\text { varchar } \\
(255)\end{array}$} & $\mathrm{Ya}$ & Tidak \\
\hline catatan_kembali & \multicolumn{2}{|l|}{ Catatan } & \multicolumn{2}{|c|}{$\begin{array}{l}\text { varchar } \\
(255)\end{array}$} & $\mathrm{Ya}$ & Tidak \\
\hline \multicolumn{7}{|c|}{ Indeks Tabel } \\
\hline \multirow[t]{2}{*}{ Nama Indeks } & \multirow{2}{*}{\begin{tabular}{c|} 
Nama \\
Kolom
\end{tabular}} & \multirow{2}{*}{\multicolumn{2}{|c|}{\begin{tabular}{c|} 
Jenis \\
Indeks
\end{tabular}}} & \multicolumn{3}{|c|}{ Referensi } \\
\hline & & & & & & Kolom \\
\hline $\begin{array}{c}\text { fk_peminjaman } \\
\text { laptop }\end{array}$ & id_laptop & $\begin{array}{r}\text { For } \\
\mathrm{K}\end{array}$ & eign & MDI & ptop & id_laptop \\
\hline $\begin{array}{c}\text { fk_peminjaman } \\
\text { _adminpinjam }\end{array}$ & $\begin{array}{c}\text { Admin } \\
\text { _pinjam }\end{array}$ & For & eign & Kary & & $\begin{array}{c}\text { id_- } \\
\text { karyawa }\end{array}$ \\
\hline $\begin{array}{l}\text { fk_peminjaman } \\
\text { _adminkembali }\end{array}$ & id_ram & $\begin{array}{r}\text { For } \\
\mathrm{K} \\
\end{array}$ & eign & & & $\begin{array}{c}\text { id__ } \\
\text { karyaw }\end{array}$ \\
\hline
\end{tabular}

Diagram Entity Relationship Diagram (ERD)

konseptual dengan primary key, unique key dan foreign key ditunjukkan pada Gambar 13.

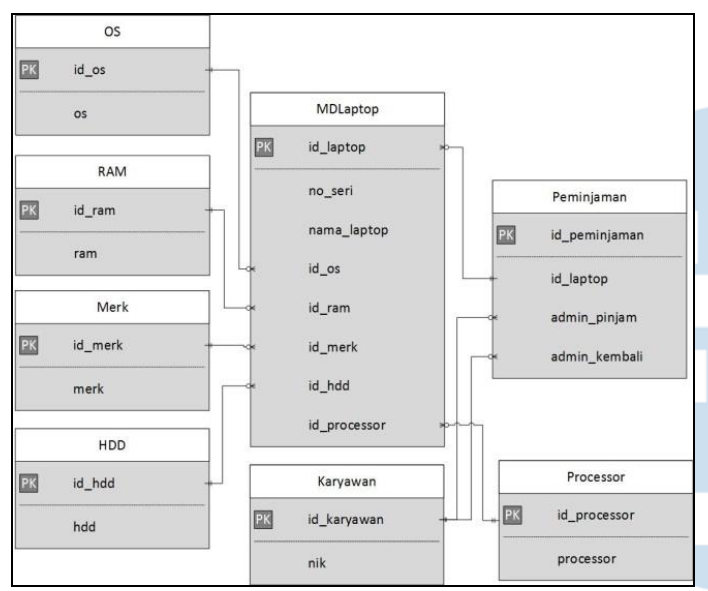

Gambar 13. ERD konseptual

Berikut ini adalah tampilan aplikasi pada akhir tahap iterasi kedua.

Halaman Transaksi Peminjaman digunakan untuk menampilkan dan mengelola data transaksi peminjaman dan menginput data mengembalian laptop.

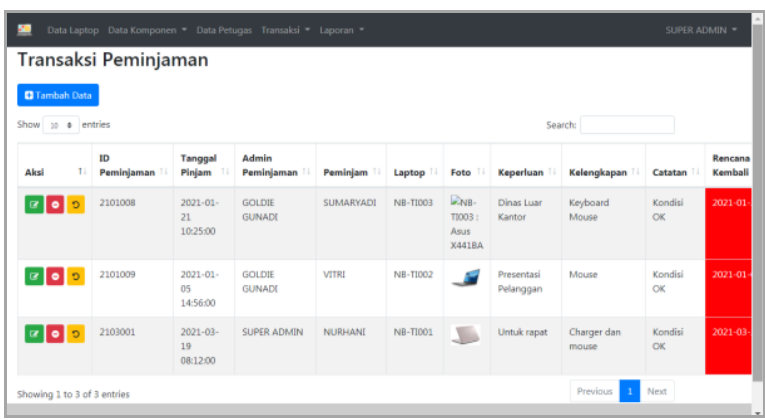

Gambar 14. Tampilan halaman transaksi peminjaman
Halaman Transaki Pengembalian digunakan untuk menampilkan dan mengelola data transaksi pengembalian laptop.

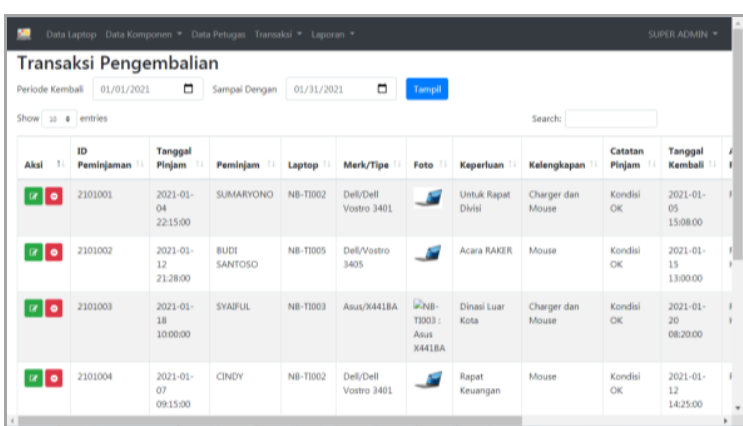

Gambar 15. Tampilan halaman transaksi pengembalian

Hasil pengujian black box untuk memastikan fungsional aplikasi pada tahap iterasi kedua telah terpenuhi.

Hasil pengujian antarmuka halaman Transaksi Peminjaman:

Tabel 17. Hasil pengujian antarmuka transaksi peminjaman

\begin{tabular}{|c|c|c|c|}
\hline $\begin{array}{l}\text { Kegiatan } \\
\text { Pengujian }\end{array}$ & $\begin{array}{c}\text { Hasil yang } \\
\text { Diharapkan }\end{array}$ & $\begin{array}{c}\text { Hasil } \\
\text { Pengujian }\end{array}$ & $\begin{array}{c}\text { Kesim- } \\
\text { pulan }\end{array}$ \\
\hline $\begin{array}{l}\text { Menampilkan } \\
\text { daftar } \\
\text { transaksi } \\
\text { peminjaman } \\
\text { laptop yang } \\
\text { terimpan. }\end{array}$ & $\begin{array}{l}\text { Sistem } \\
\text { menampilkan } \\
\text { seluruh data } \\
\text { transaksi } \\
\text { peminjaman yang } \\
\text { tersimpan dalam } \\
\text { basis data. }\end{array}$ & $\begin{array}{l}\text { Seluruh data } \\
\text { transaksi } \\
\text { peminjaman } \\
\text { ditampilkan. }\end{array}$ & Sukses \\
\hline $\begin{array}{l}\text { Menambah } \\
\text { data transaksi } \\
\text { peminjaman. }\end{array}$ & $\begin{array}{l}\text { Sistem } \\
\text { menampilkan } \\
\text { form input data } \\
\text { transaksi } \\
\text { peminjaman. } \\
\text { Sistem } \\
\text { menyimpan data } \\
\text { transaksi } \\
\text { peminjaman baru } \\
\text { ke dalam basis } \\
\text { data. }\end{array}$ & $\begin{array}{l}\text { Form input } \\
\text { ditampilkan. } \\
\text { Data transaksi } \\
\text { peminjaman } \\
\text { baru berhasil } \\
\text { disimpan dalam } \\
\text { basis data. }\end{array}$ & Sukses \\
\hline $\begin{array}{l}\text { Merubah data } \\
\text { transaksi } \\
\text { peminjaman. }\end{array}$ & $\begin{array}{l}\text { Sistem } \\
\text { menampilkan } \\
\text { form edit data } \\
\text { transaksi } \\
\text { peminjaman. } \\
\text { Sistem } \\
\text { menyimpan } \\
\text { perubahan data } \\
\text { transaksi } \\
\text { peminjaman pada } \\
\text { basis data. }\end{array}$ & $\begin{array}{l}\text { Form edit } \\
\text { ditampilkan. } \\
\text { Perubahan data } \\
\text { transaksi } \\
\text { peminjaman } \\
\text { berhasil } \\
\text { disimpan pada } \\
\text { basis data. }\end{array}$ & Sukses \\
\hline $\begin{array}{l}\text { Menghapus } \\
\text { data transaksi } \\
\text { peminjaman. }\end{array}$ & $\begin{array}{l}\text { Sistem } \\
\text { menampilkan } \\
\text { permintaan } \\
\text { konfirmasi hapus }\end{array}$ & $\begin{array}{l}\text { Permintaan } \\
\text { konfirmasi } \\
\text { ditampilkan. } \\
\text { Data transaksi }\end{array}$ & Sukses \\
\hline
\end{tabular}




\begin{tabular}{|c|c|c|c|}
\hline & $\begin{array}{l}\text { data transaksi } \\
\text { peminjaman. } \\
\text { Sistem } \\
\text { menghapus data } \\
\text { transaksi } \\
\text { peminjaman dari } \\
\text { basis data. }\end{array}$ & $\begin{array}{l}\text { peminjaman } \\
\text { berhasil } \\
\text { dihapus dari } \\
\text { basis data. }\end{array}$ & \\
\hline $\begin{array}{l}\text { Menyimpan } \\
\text { data transaski } \\
\text { pengembalian } \\
\text { laptop. }\end{array}$ & $\begin{array}{l}\text { Sistem } \\
\text { menampilkan } \\
\text { form input data } \\
\text { transaksi } \\
\text { pengembalian. } \\
\text { Sistem } \\
\text { menyimpan data } \\
\text { transaksi } \\
\text { pengembalian } \\
\text { pada basis data. }\end{array}$ & $\begin{array}{l}\text { Form input data } \\
\text { transaksi } \\
\text { pengembalian } \\
\text { ditampilkan. } \\
\text { Data transaksi } \\
\text { pengembalian } \\
\text { berhasil } \\
\text { disimpan pada } \\
\text { basis data. }\end{array}$ & Sukses \\
\hline
\end{tabular}

Hasil pengujian antarmuka halaman Transaksi Pengembalian:

Tabel 18. Hasil pengujian antarmuka transaksi pengembalian

\begin{tabular}{|c|c|c|c|}
\hline $\begin{array}{c}\text { Kegiatan } \\
\text { Pengujian }\end{array}$ & $\begin{array}{c}\text { Hasil yang } \\
\text { Diharapkan }\end{array}$ & $\begin{array}{c}\text { Hasil } \\
\text { Pengujian }\end{array}$ & $\begin{array}{l}\text { Kesim- } \\
\text { pulan }\end{array}$ \\
\hline $\begin{array}{l}\text { Menampilkan } \\
\text { daftar } \\
\text { transaksi } \\
\text { pengembalian } \\
\text { laptop yang } \\
\text { terimpan } \\
\text { berdasarkan } \\
\text { periode } \\
\text { tertentu. }\end{array}$ & $\begin{array}{l}\text { Sistem } \\
\text { menampilkan } \\
\text { seluruh data } \\
\text { transaksi } \\
\text { peminjaman yang } \\
\text { tersimpan dalam } \\
\text { basis data sesuai } \\
\text { periode waktu } \\
\text { yang ditentukan. }\end{array}$ & $\begin{array}{l}\text { Data transaksi } \\
\text { peminjaman } \\
\text { sesuai periode } \\
\text { waktu tertentu } \\
\text { ditampilkan. }\end{array}$ & Sukses \\
\hline $\begin{array}{l}\text { Merubah data } \\
\text { transaksi } \\
\text { pengembalian }\end{array}$ & \begin{tabular}{|l|} 
Sistem \\
menampilkan \\
form edit data \\
transaksi \\
pengembalian. \\
Sistem \\
menyimpan \\
perubahan data \\
transaksi \\
pengembalian \\
pada basis data.
\end{tabular} & $\begin{array}{l}\text { Form edit } \\
\text { ditampilkan. } \\
\text { Perubahan } \\
\text { data transaksi } \\
\text { pengembalian } \\
\text { berhasil } \\
\text { disimpan pada } \\
\text { basis data. }\end{array}$ & Sukses \\
\hline $\begin{array}{l}\text { Menghapus } \\
\text { data transaksi } \\
\text { pengembalian }\end{array}$ & $\begin{array}{l}\text { Sistem } \\
\text { menampilkan } \\
\text { permintaan } \\
\text { konfirmasi hapus } \\
\text { data transaksi } \\
\text { pengembalian. } \\
\text { Sistem } \\
\text { menghapus data } \\
\text { transaksi } \\
\text { pengembalian } \\
\text { dari basis data. }\end{array}$ & \begin{tabular}{|l|} 
Permintaan \\
konfirmasi \\
ditampilkan. \\
Data transaksi \\
pengembalian \\
berhasil \\
dihapus dari \\
basis data.
\end{tabular} & Sukses \\
\hline
\end{tabular}

Hasil pengujian menu navigasi:

Tabel 19. Hasil pengujian menu navigasi

\begin{tabular}{|c|c|c|c|}
\hline $\begin{array}{c}\text { Kegiatan } \\
\text { Pengujian }\end{array}$ & $\begin{array}{c}\text { Hasil yang } \\
\text { Diharapkan }\end{array}$ & $\begin{array}{c}\text { Hasil } \\
\text { Pengujian }\end{array}$ & $\begin{array}{c}\text { Kesim- } \\
\text { pulan }\end{array}$ \\
\hline $\begin{array}{c}\text { Memilih } \\
\text { menu }\end{array}$ & $\begin{array}{c}\text { Menampilkan } \\
\text { halaman }\end{array}$ & $\begin{array}{c}\text { Halaman } \\
\text { Transaksi }\end{array}$ & Sukses \\
\hline
\end{tabular}

\begin{tabular}{|c|c|c|l|}
\hline Peminjaman. & $\begin{array}{c}\text { Transaksi } \\
\text { Peminjaman. }\end{array}$ & $\begin{array}{c}\text { Peminjaman } \\
\text { Laptop } \\
\text { ditampilkan. }\end{array}$ & \\
\hline Memilih & Menampilkan & Halaman & Sukses \\
menu & halaman & halaman & \\
Transaksi & $\begin{array}{c}\text { Transaksi } \\
\text { Pengembalian } \\
\text { ditampilkan. }\end{array}$ & \\
Pengembalian. & $\begin{array}{c}\mid c \\
\text { ditan }\end{array}$ & \\
\hline
\end{tabular}

3) Iterasi ketiga meliputi proses pembuatan halaman laporan transaksi peminjaman laptop berdasarkan periode waktu peminjaman dan laporan transaksi peminjaman laptop berdasarkan nama laptop tertentu.

Tabel 20 berisi sejumlah feedback dan perbaikan yang terjadi pada tahapan iterasi ketiga.

Tabel 20. Tabel feedback dan revisi iterasi kedua

\begin{tabular}{|l|l|}
\hline \multicolumn{1}{|c|}{ Feedback } & Revisi yang dilakukan \\
\hline $\begin{array}{l}\text { Menambahkan fasilitas } \\
\text { untuk menyimpan data } \\
\text { laporan peminjaman periode } \\
\text { ke dalam format Excel }\end{array}$ & $\begin{array}{l}\text { • Perubahan kode } \\
\text { program laporan } \\
\text { peminjaman } \\
\text { berdasarkan periode. }\end{array}$ \\
\hline $\begin{array}{l}\text { Menambahkan fasilitas } \\
\text { untuk menyimpan data } \\
\text { laporan peminjaman laptop } \\
\text { ke dalam format Excel }\end{array}$ & $\begin{array}{l}\text { • Perubahan kode } \\
\text { program laporan } \\
\text { peminjaman } \\
\text { berdasarkan laptop. }\end{array}$ \\
\hline $\begin{array}{l}\text { Merubah format tampilan isi } \\
\text { kolom 'Tanggal Pinjam' dan } \\
\text { 'Tanggal Kembali' pada } \\
\text { hasil laporan peminjaman } \\
\text { periode menjadi format : } \\
\text { dd/mm/yyyy hh:mm', }\end{array}$ & $\begin{array}{l}\text { Perubahan kode } \\
\text { program laporan } \\
\text { peminjaman }\end{array}$ \\
\hline $\begin{array}{l}\text { Merubah format tampilan isi } \\
\text { kolom 'Tanggal Pinjam' dan } \\
\text { 'Tanggal Kembali' pada } \\
\text { hasil laporan peminjaman } \\
\text { laptop menjadi format : } \\
\text { dd/mm/yyyy hh:mm' }\end{array}$ & $\begin{array}{l}\text { Perubahan kode } \\
\text { program laporan } \\
\text { peminjaman }\end{array}$ \\
\hline
\end{tabular}

Berikut ini adalah tampilan aplikasi pada akhir tahap iterasi ketiga.

Halaman Laporan Peminjaman Periode digunakan untuk menampilkan, mencetak dan menyimpan data transaksi peminjaman laptop berdasarkan periode waktu tertentu.

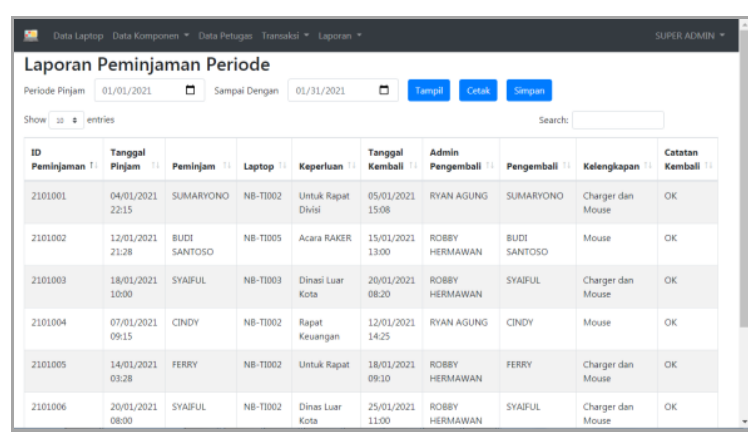

Gambar 16. Tampilan halaman laporan peminjaman periode 
Halaman Laporan Peminjaman Laptop, digunakan untuk menampilkan, mencetak dan menyimpan data transaksi peminjaman laptop tertentu.

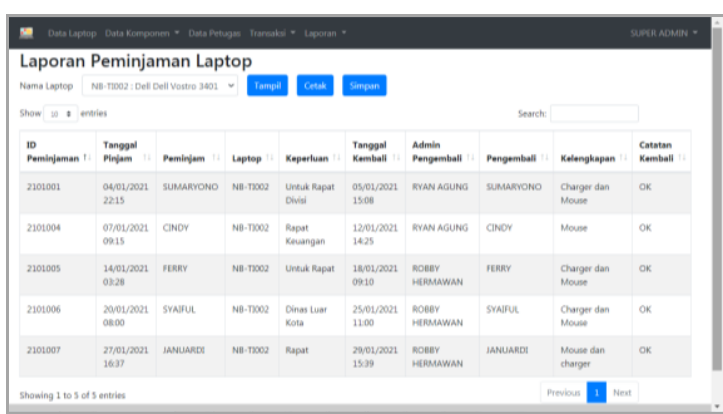

Gambar 17. Tampilan halaman laporan peminjaman laptop

Hasil pengujian black box untuk memastikan fungsional aplikasi pada tahap iterasi ketiga telah terpenuhi.

Hasil pengujian antarmuka halaman Laporan Peminjaman Periode dan Laporan Peminjaman Laptop dapat dilihat pada Tabel 21.

Tabel 21. Hasil pengujian antarmuka halaman laporan peminjaman periode dan peminjaman laptop

\begin{tabular}{|c|c|c|c|}
\hline $\begin{array}{c}\text { Kegiatan } \\
\text { Pengujian } \\
\end{array}$ & \begin{tabular}{|c|} 
Hasil yang \\
Diharapkan \\
\end{tabular} & \begin{tabular}{|c|} 
Hasil \\
Pengujian \\
\end{tabular} & $\begin{array}{l}\text { Kesim- } \\
\text { pulan }\end{array}$ \\
\hline $\begin{array}{l}\text { Menampilkan } \\
\text { tabel data } \\
\text { transaksi } \\
\text { peminjaman } \\
\text { dan } \\
\text { pengembalian } \\
\text { laptop sesuai } \\
\text { dengan } \\
\text { parameter } \\
\text { yang } \\
\text { ditentukan. }\end{array}$ & $\begin{array}{l}\text { Sistem } \\
\text { menampilkan } \\
\text { data transaksi } \\
\text { peminjaman } \\
\text { dan } \\
\text { pengembalian } \\
\text { laptop sesuai } \\
\text { dengan } \\
\text { parameter yang } \\
\text { ditentukan. }\end{array}$ & $\begin{array}{l}\text { Seluruh data } \\
\text { transaksi } \\
\text { peminjaman } \\
\text { dan } \\
\text { pengembalian } \\
\text { laptop sesuai } \\
\text { dengan } \\
\text { parameter yang } \\
\text { ditentukan } \\
\text { berhasil } \\
\text { ditampilkan. } \\
\end{array}$ & Sukses \\
\hline $\begin{array}{l}\text { Menampilkan } \\
\text { tampilan cetak } \\
\text { berisi data } \\
\text { transaksi } \\
\text { peminjaman } \\
\text { dan } \\
\text { pengembalian } \\
\text { laptop sesuai } \\
\text { dengan } \\
\text { parameter } \\
\text { yang } \\
\text { ditentukan. }\end{array}$ & $\begin{array}{l}\text { Sistem } \\
\text { menampilkan } \\
\text { tampilan cetak } \\
\text { berisi data } \\
\text { transaksi } \\
\text { peminjaman } \\
\text { dan } \\
\text { pengembalian } \\
\text { laptop sesuai } \\
\text { dengan } \\
\text { parameter yang } \\
\text { ditentukan. }\end{array}$ & $\begin{array}{l}\text { Seluruh data } \\
\text { transaksi } \\
\text { peminjaman } \\
\text { dan } \\
\text { pengembalian } \\
\text { laptop sesuai } \\
\text { dengan } \\
\text { parameter yang } \\
\text { ditentukan } \\
\text { berhasil } \\
\text { ditampilkan } \\
\text { dalam bentuk } \\
\text { tampilan cetak. } \\
\end{array}$ & Sukses \\
\hline $\begin{array}{l}\text { Menyimpan } \\
\text { data transaksi } \\
\text { peminjaman } \\
\text { dan } \\
\text { pengembalian } \\
\text { laptop sesuai } \\
\text { dengan } \\
\text { parameter } \\
\text { yang }\end{array}$ & $\begin{array}{l}\text { Sistem } \\
\text { menyimpan } \\
\text { data transaksi } \\
\text { peminjaman } \\
\text { dan } \\
\text { pengembalian } \\
\text { laptop sesuai } \\
\text { dengan } \\
\text { parameter yang } \\
\end{array}$ & \begin{tabular}{|l} 
Seluruh data \\
transaksi \\
peminjaman \\
dan \\
pengembalian \\
laptop sesuai \\
dengan \\
parameter yang \\
ditentukan \\
\end{tabular} & Sukses \\
\hline
\end{tabular}

Ultima InfoSys : Jurnal Ilmu Sistem Informasi, Vol. 12, No. 1 | Juni 2021

\begin{tabular}{|l|l|l|l|}
\hline ditentukan & ditentukan & berhasil & \\
dalam bentuk & dalam bentuk & disimpan dalam & \\
dokumen & dokumen & bentuk & \\
Excel. & Excel. & dokumen Excel. & \\
\hline
\end{tabular}

Pengujian menu navigasi.

Tabel 22. Hasil pengujian menu navigasi

\begin{tabular}{|c|c|c|c|}
\hline $\begin{array}{l}\text { Kegiatan } \\
\text { Pengujian }\end{array}$ & $\begin{array}{c}\text { Hasil yang } \\
\text { Diharapkan }\end{array}$ & $\begin{array}{c}\text { Hasil } \\
\text { Pengujian }\end{array}$ & $\begin{array}{l}\text { Kesim- } \\
\text { pulan }\end{array}$ \\
\hline $\begin{array}{l}\text { Memilih } \\
\text { menu } \\
\text { Laporan } \\
\text { Peminjaman } \\
\text { Periode. } \\
\end{array}$ & $\begin{array}{l}\text { Menampilkan } \\
\text { halaman Laporan } \\
\text { Peminjaman } \\
\text { Periode. }\end{array}$ & $\begin{array}{l}\text { Halaman } \\
\text { Laporan } \\
\text { Peminjaman } \\
\text { Periode } \\
\text { ditampilkan. }\end{array}$ & Sukses \\
\hline $\begin{array}{l}\text { Memilih } \\
\text { menu } \\
\text { Laporan } \\
\text { Peminjaman } \\
\text { Laptop. }\end{array}$ & $\begin{array}{l}\text { Menampilkan } \\
\text { halaman Laporan } \\
\text { Peminjaman } \\
\text { Laptop. }\end{array}$ & $\begin{array}{l}\text { Halaman } \\
\text { halaman } \\
\text { Laporan } \\
\text { Peminjaman } \\
\text { Laptop } \\
\text { ditampilkan. } \\
\end{array}$ & Sukses \\
\hline
\end{tabular}

\section{User Acceptance Test (UAT)}

Proses pengujian dilakukan dengan melakukan UAT kepada 5 orang responder yang terdiri dari: 1 orang IT Operation Manager, 1 orang IT Engineer, 1 orang Helpdesk Superintendent, dan 2 orang Technician.

Hasil proses pengujian yang dilakukan dapat dilihat pada tabel berikut:

Tabel 23. Hasil jawaban UAT

\begin{tabular}{|c|c|c|c|c|c|c|}
\hline \multirow[t]{2}{*}{ Kode } & \multirow[t]{2}{*}{ Pertanyaan } & \multicolumn{5}{|c|}{ Jawaban } \\
\hline & & SS & $\mathbf{S}$ & $\mathbf{N}$ & $\begin{array}{l}\mathbf{T} \\
\mathbf{S}\end{array}$ & $\begin{array}{c}\text { ST } \\
\text { S }\end{array}$ \\
\hline Sub 1 & Tampilan Aplikasi & & & & & \\
\hline 1.1 & Tampilan aplikasi menarik & 0 & 4 & 1 & 0 & 0 \\
\hline 1.2 & $\begin{array}{l}\text { Aplikasi dapat ditampilkan } \\
\text { dengan baik pada perangkat } \\
\text { smartphone }\end{array}$ & 2 & 3 & 0 & 0 & 0 \\
\hline 1.3 & $\begin{array}{l}\text { Aplikasi dapat ditampilkan } \\
\text { dengan baik pada perangkat } \\
\text { laptop/PC }\end{array}$ & 5 & 0 & 0 & 0 & 0 \\
\hline Sub 2 & Fitur Aplikasi & & & & & \\
\hline 2.1 & $\begin{array}{l}\text { Fitur-fitur yang tersedia sudah } \\
\text { sesuai dengan kebutuhan }\end{array}$ & 4 & 1 & 0 & 0 & 0 \\
\hline 2.2 & $\begin{array}{l}\text { Keseluruhan fitur yang tersedia } \\
\text { sudah berjalan dengan baik }\end{array}$ & 3 & 2 & 0 & 0 & 0 \\
\hline Sub 3 & Kemudahan Penggunaan & & & & & \\
\hline 3.1 & $\begin{array}{l}\text { Menu-menu yang tersedia } \\
\text { mudah dipahami }\end{array}$ & 4 & 1 & 0 & 0 & 0 \\
\hline 3.2 & $\begin{array}{l}\text { Aplikasi mudah dipahami dan } \\
\text { digunakan }\end{array}$ & 3 & 2 & 0 & 0 & 0 \\
\hline 3.3 & $\begin{array}{l}\text { Setiap pesan kesalahan yang } \\
\text { muncul dapat dipahami }\end{array}$ & 5 & 0 & 0 & 0 & 0 \\
\hline Sub 4 & Efektivitas Aplikasi & & & & & \\
\hline 4.1 & $\begin{array}{l}\text { Setiap pengolahan data dapat } \\
\text { dilakukan dengan cepat }\end{array}$ & 0 & 4 & 1 & 0 & 0 \\
\hline 4.2 & $\begin{array}{l}\text { Proses administrasi } \\
\text { peminjaman laptop dapat } \\
\text { dilakukan dengan baik melalui } \\
\text { aplikasi }\end{array}$ & 1 & 4 & 0 & 0 & 0 \\
\hline
\end{tabular}


Berikut adalah data bobot nilai dari pilihan jawaban pertanyaan : Sangat Setuju $(\mathrm{SS})=5$, Setuju $(\mathrm{S})=4$, Netral $(\mathrm{N})=3$, Tidak Setuju $=2$, Sangat Tidak Setuju $($ STS $)=1$.

Berikut hasil analisa terhadap jawaban responder:

Tabel 24. Hasil jawaban UAT

\begin{tabular}{|c|c|c|c|c|c|c|c|c|c|}
\hline \multirow[t]{2}{*}{ Sub } & \multirow[t]{2}{*}{ Kode } & \multicolumn{5}{|c|}{ Nilai Jawaban } & \multirow{2}{*}{$\begin{array}{l}\text { Total } \\
\text { Nilai }\end{array}$} & \multirow{2}{*}{$\begin{array}{c}\text { Rata- } \\
\text { rata }\end{array}$} & \multirow{2}{*}{$\begin{array}{l}\text { Persen- } \\
\text { tase }\end{array}$} \\
\hline & & SS & $\mathbf{S}$ & $\mathbf{N}$ & $\begin{array}{l}\mathbf{T} \\
\mathbf{S}\end{array}$ & STS & & & \\
\hline \multirow[t]{3}{*}{1} & 1.1 & 0 & $\begin{array}{l}1 \\
6\end{array}$ & 3 & 0 & 0 & 19 & 3,8 & $76 \%$ \\
\hline & 1.2 & 10 & $\begin{array}{l}1 \\
2\end{array}$ & 0 & 0 & 0 & 22 & 4,4 & $88 \%$ \\
\hline & 1.3 & 25 & 0 & 0 & 0 & 0 & 25 & 5 & $100 \%$ \\
\hline \multirow[t]{2}{*}{2} & 2.1 & 20 & 4 & 0 & 0 & 0 & 24 & 4,8 & $96 \%$ \\
\hline & 2.2 & 15 & 8 & 0 & 0 & 0 & 23 & 4,6 & $92 \%$ \\
\hline \multirow[t]{3}{*}{3} & 3.1 & 20 & 4 & 0 & 0 & 0 & 24 & 4,8 & $96 \%$ \\
\hline & 3.2 & 15 & 8 & 0 & 0 & 0 & 23 & 4,6 & $92 \%$ \\
\hline & 3.3 & 25 & 0 & 0 & 0 & 0 & 25 & 5 & $100 \%$ \\
\hline \multirow[t]{2}{*}{4} & 4.1 & 0 & $\begin{array}{l}1 \\
6 \\
\end{array}$ & 3 & 0 & 0 & 19 & 3,8 & $76 \%$ \\
\hline & 4.2 & 5 & $\begin{array}{l}1 \\
6 \\
\end{array}$ & 0 & 0 & 0 & 21 & 4,2 & $84 \%$ \\
\hline
\end{tabular}

Hasil analisa UAT Sistem Peminjaman Laptop:

1) Persentase dari tingkat penerimaan pengguna terhadap tampilan aplikasi (Sub 1) sebesar : $(76 \%$ $+88 \%+100 \%) / 3=88 \%$.

2) Persentase dari tingkat penerimaan pengguna terhadap fitur aplikasi (Sub 2) sebesar : $(96 \%+$ $92 \%) / 2=94 \%$.

3) Persentase dari tingkat penerimaan pengguna terhadap kemudahan penggunaan aplikasi (Sub 3) sebesar : $(96 \%+92 \%+100 \%) / 3=96 \%$.

4) Persentase dari tingkat penerimaan pengguna terhadap fitur efektivitas aplikasi (Sub 4) : $(76 \%+$ $84 \%) / 2=80 \%$.

\section{SIMPULAN}

Dari penelitian yang dilakukan ini dapat diambil kesimpulan bahwa pengembangan sistem informasi peminjaman laptop berbasis web dengan menggunakan metode XP dapat menjadi salah satu kekuatan bagi PT Gramedia dalam menghadapi tantangan bisnis yang diakibatkan adanya pandemi COVID-19. Dengan adanya sistem informasi peminjaman laptop, proses administrasi dapat dilakukan dengan lebih efektif dan efisien, sehingga setiap kebutuhan karyawan terhadap perangkat laptop dapat terpenuhi dengan baik.

Dengan menggunakan framework Bootstrap proses pembuatan antarmuka pengguna dapat menjadi lebih cepat, mudah dan terstruktur, sehingga tampilan aplikasi yang dihasilkan menjadi lebih interaktif, menarik dan responsif pada berbagai perangkat yang berbeda.
Hasil evaluasi menunjukkan tingkat kepuasan pengguna terhadap tampilan antar muka, fitur, kemudahan penggunaan serta efektivitas aplikasi menunjukkan hasil yang sangat baik dengan nilai rata-rata 89,5 dalam skala 100 .

Sebagai saran untuk pengembangan sistem peminjaman laptop di PT Gramedia adalah dengan menambahkan fasilitas dimana karyawan yang akan meminjam laptop dapat mengakses sistem untuk melakukan permintaan (request) peminjaman. Dengan begitu karyawan juga dapat memastikan ketersediaan laptop yang akan dipinjam terlebih dahulu dan melakukan proses booking untuk laptop yang akan dipinjamnya melalui sistem. Hal ini akan memudahkan pihak administrasi peminjaman untuk memutuskan kepada siapa berikutnya laptop akan dipinjamkan berdasarkan prioritas kepentingan calon peminjam.

\section{UCAPAN TERIMA KASIH}

Penulis mengucapkan terima kasih kepada GM Information Technology PT Gramedia yang telah memberi izin dan kesempatan untuk melakukan penelitian ini.

\section{DAFTAR PUSTAKA}

[1] P. Gramedia, "Profile." http://gramediaprinting.com/profile (accessed Feb. 24, 2021).

[2] B. A. Oktavira, "Ketentuan Pelaksanaan Work From Home di Tengah Wabah COVID-19," 2020 https://www.hukumonline.com/klinik/detail/ulasan/lt5e7326f d25227/ketentuan-pelaksanaan-i-work-from-home-i-ditengah-wabah-corona/.

[3] Y. Budiarti and R. Risyanto, "Implementasi Metode Extreme Programming Untuk Merancang Sistem Informasi Pendaftaran Siswa Baru Berbasis Web Pada Smk Multimedia Mandiri Jakarta," J. Inform., vol. 8, no. 1, pp. 1-9, 2020, doi: 10.36987/informatika.v8i1.1402.

[4] I. G. N. Suryantara, Merancang Aplikasi dengan Metodologi Extreme Programmings. PT. Elex Media Komputindo, 2017.

[5] D. Andika, "Apa itu Extreme Programming??" https://www.it-jurnal.com/apa-itu-extreme-programming/ (accessed Feb. 24, 2021).

[6] R. I. Bormana, A. T. Priandika, and Arif Rahman Edisona, "Implementasi Metode Pengembangan Sistem Extreme Programming (XP) pada Aplikasi Investasi Peternakane," $J$. Sist. dan Teknol. Inf., vol. 8 No. 3, 2020.

[7] J. Enterprise, Pemrograman Bootstrap untuk Pemula. PT. Elex Media Komputindo, 2016.

[8] Z. A. Rozi, Bootstrap Design Framework. Jakarta: PT. Elex Media Komputindo, 2015.

[9] B. Team, "Build fast, responsive sites with Bootstrap." https://getbootstrap.com/ (accessed Jan. 06, 2021).

[10] Https://id.wikipedia.org/wiki/Extreme_programming, "Extreme programming."

[11] R. A.S. and M. Shalahuddin, Rekayasa Perangkat Lunak: Terstruktur dan Berorientasi Objek. Informatika Bandung, 2014.

[12] R. S. Pressman, REKAYASA PERANGKAT LUNAK PENDEKATAN PRAKTISI (BUKU 1), 7th ed. Penerbit Andi.

[13] Getbootstrap.com, https://getbootstrap.com/docs/4.0/gettingstarted/introduction/. 